Prepared in cooperation with the Teton Conservation District

\title{
Chloride Concentrations and Stable Isotopes of Hydrogen and Oxygen in Surface Water and Groundwater in and near Fish Creek, Teton County, Wyoming, 2005-06
}

Data Series 518

U.S. Department of the Interior U.S. Geological Survey 
Cover. Fish Creek at site A-RB, August 2007. Photograph by Jerrod Wheeler. 


\section{Chloride Concentrations and Stable Isotopes of Hydrogen and Oxygen in Surface Water and Groundwater in and near Fish Creek, Teton County, Wyoming, 2005-06}

By Cheryl A. Eddy-Miller and Jerrod D. Wheeler

Prepared in cooperation with the Teton Conservation District

Data Series 518 


\title{
U.S. Department of the Interior \\ KEN SALAZAR, Secretary \\ U.S. Geological Survey \\ Marcia K. McNutt, Director
}

\section{U.S. Geological Survey, Reston, Virginia: 2010}

\author{
For more information on the USGS — the Federal source for science about the Earth, its natural and living resources, \\ natural hazards, and the environment, visit http://www.usgs.gov or call 1-888-ASK-USGS \\ For an overview of USGS information products, including maps, imagery, and publications, \\ visit http://www.usgs.gov/pubprod \\ To order this and other USGS information products, visit http://store.usgs.gov
}

\begin{abstract}
Any use of trade, product, or firm names is for descriptive purposes only and does not imply endorsement by the U.S. Government.

Although this report is in the public domain, permission must be secured from the individual copyright owners to reproduce any copyrighted materials contained within this report.
\end{abstract}

Suggested citation:

Eddy-Miller, C.A., and Wheeler, J.D., 2010, Chloride concentrations and stable isotopes of hydrogen and oxygen in surface water and groundwater in and near Fish Creek, Teton County, Wyoming, 2005-06: U.S. Geological Survey Data Series 518, 12 p. 


\section{Contents}

Abstract
Introduction
Purpose and Scope

\section{Figures}

1-2. Maps showing:

1. Location of Fish Creek as part of the Jackson Hole valley, Wyoming ........................2

2. Locations of three well cross sections and selected miscellaneous water-quality sampling sites on and near Fish Creek, Wyoming..................................

3. Channel geometry and well network at cross sections for Teton Village, Resor's Bridge, and Wilson

4-6. Graphs showing:

4. $\delta^{18} 0$ and $\delta^{2} \mathrm{H}$ pairs from water samples collected from surface water and groundwater at the Teton Village cross section on Fish Creek in relation to the Global Meteoric Water Line and Local Meteoric Water Line

5. $\delta^{18} 0$ and $\delta^{2} \mathrm{H}$ pairs from water samples collected from surface water and groundwater at the Resor's Bridge cross section on Fish Creek in relation to the Global Meteoric Water Line and Local Meteoric Water Line.

6. $\delta^{18} 0$ and $\delta^{2} \mathrm{H}$ pairs from water samples collected from surface water and groundwater at the Wilson cross section on Fish Creek in relation to the Global Meteoric Water Line and Local Meteoric Water Line

\section{Tables}

1. Name and location of surface-water and groundwater water-quality sampling sites at the Teton Village, Resor's Bridge, and Wilson cross sections on Fish Creek, and miscellaneous sampling sites ..

2. Concentration of chloride in water samples collected from surface water and groundwater at Teton Village, Resor's Bridge, and Wilson cross sections on Fish Creek, and nearby surface-water bodies.

3. Composition of isotopic fractions of hydrogen and oxygen in water samples collected from surface water and groundwater at Teton Village, Resor's Bridge, and Wilson cross sections on Fish Creek, and nearby surface-water bodies 


\section{Conversion Factors}

\begin{tabular}{|c|c|c|}
\hline Multiply & By & To obtain \\
\hline \multicolumn{3}{|c|}{ Length } \\
\hline centimeter $(\mathrm{cm})$ & 0.3937 & inch (in) \\
\hline meter $(\mathrm{m})$ & 3.281 & foot $(\mathrm{ft})$ \\
\hline kilometer (km) & 0.6214 & mile (mi) \\
\hline \multicolumn{3}{|c|}{ Area } \\
\hline square kilometer $\left(\mathrm{km}^{2}\right)$ & 0.3861 & square mile $\left(\mathrm{mi}^{2}\right)$ \\
\hline \multicolumn{3}{|c|}{ Volume } \\
\hline liter $(\mathrm{L})$ & 0.2642 & gallon (gal) \\
\hline milliliter (mL) & 0.03382 & ounce, fluid (fl.oz) \\
\hline
\end{tabular}

Horizontal coordinate information is referenced to North American Datum of 1983 (NAD 83).

Altitude, as used in this report, refers to distance above the vertical datum.

Concentrations of chloride are given in milligrams per liter (mg/L).

Stable isotope values of hydrogen and oxygen are referenced to a standard and are given in parts per thousand or per mil.

\section{Acronyms}

GMWL Global Meteoric Water Line

LMWL Local Meteoric Water Line 


\title{
Chloride Concentrations and Stable Isotopes of Hydrogen and Oxygen in Surface Water and Groundwater in and near Fish Creek, Teton County, Wyoming, 2005-06
}

\author{
By Cheryl A. Eddy-Miller and Jerrod D. Wheeler
}

\begin{abstract}
Fish Creek, an approximately 25-kilometer long tributary to the Snake River, is located in Teton County in western Wyoming near the town of Wilson. The U.S. Geological Survey, in cooperation with the Teton Conservation District, conducted a study to determine the interaction of local surface water and groundwater in and near Fish Creek. In conjunction with the surface water and groundwater interaction study, samples were collected for analysis of chloride and stable isotopes of hydrogen and oxygen in water.

Chloride concentrations ranged from 2.9 to 26.4 milligrams per liter (mg/L) near Teton Village, 1.2 to $4.9 \mathrm{mg} / \mathrm{L}$ near Resor's Bridge, and 1.8 to $5.0 \mathrm{mg} / \mathrm{L}$ near Wilson. Stable isotope data for hydrogen and oxygen in water samples collected in and near the three cross sections on Fish Creek are shown in relation to the Global Meteoric Water Line and the Local Meteoric Water Line.
\end{abstract}

\section{Introduction}

Fish Creek, an approximately 25-kilometer long tributary to the Snake River, is located in Teton County in western Wyoming near the town of Wilson (figs. 1 and 2). The Fish Creek drainage is located along the southwestern margin of a structural basin known as Jackson Hole. Fish Creek's drainage area includes part of the southern extent of the Teton Range and the southwestern part of the Jackson Hole valley, and is 183 square kilometers $\left(\mathrm{km}^{2}\right)$ at the U.S. Geological Survey (USGS) streamflow-gaging station, Fish Creek at Wilson, Wyo. (station 13016450; fig. 2) (Swanson and others, 2002).

Public concern about nuisance growths of aquatic plants in Fish Creek has been increasing in recent years. To more fully understand the hydrologic system and its possible relation to aquatic life in the stream, the USGS, in cooperation with the Teton Conservation District, conducted a study to determine the interaction of local surface water and groundwater in and near Fish Creek (Wheeler and Eddy-Miller, 2005;
Eddy-Miller and others, 2009). To accomplish this, three streambed cross sections were established at Teton Village, Resor's Bridge, and Wilson (fig. 2), with the cross sections selected to represent upstream, mid-section, and downstream locations, respectively (Eddy-Miller and others, 2009). Each cross section had five wells constructed from 3.2-centimeter (cm; 11/4-inch) diameter galvanized pipe with eight, 0.6-cm diameter holes drilled into the bottom of the pipe to act as a screen. All three sites had two wells on the left bank (looking downstream by protocol), which represented the eastern side of the stream, one in the center of the stream, and two on the right bank, which represented the western side of the stream (fig. 3; table 1). In conjunction with the surface water and groundwater interaction study, samples were collected for analysis of chloride and stable isotopes of hydrogen $\left({ }^{2} \mathrm{H}\right.$, deuterium; and $\left.{ }^{1} \mathrm{H}\right)$ and oxygen $\left({ }^{18} \mathrm{O}\right.$ and $\left.{ }^{16} \mathrm{O}\right)$ in water.

\section{Purpose and Scope}

The purpose of this report is to present the chloride concentration data and the hydrogen and oxygen isotope data collected from the surface water and groundwater in and near Fish Creek in 2005 and 2006. Graphs showing the stable isotope data for hydrogen and oxygen in relation to the Global Meteoric Water Line (GMWL; Clark and Fritz, 1997) and to the Local Meteoric Water Line (LMWL; Benjamin and others, 2004) also are presented. No interpretation of the data is presented.

\section{Acknowledgments}

The authors gratefully acknowledge the generous assistance of landowners near Fish Creek, Wyo., who provided access to their property for this study. Also acknowledged are Marisa Cox and Doug Choy, USGS, for water-quality and stable isotope analyses. James E. Constantz, Katharine Foster, Lisa Binder, and Janet Carter, USGS, are acknowledged for their reviews of this report. 


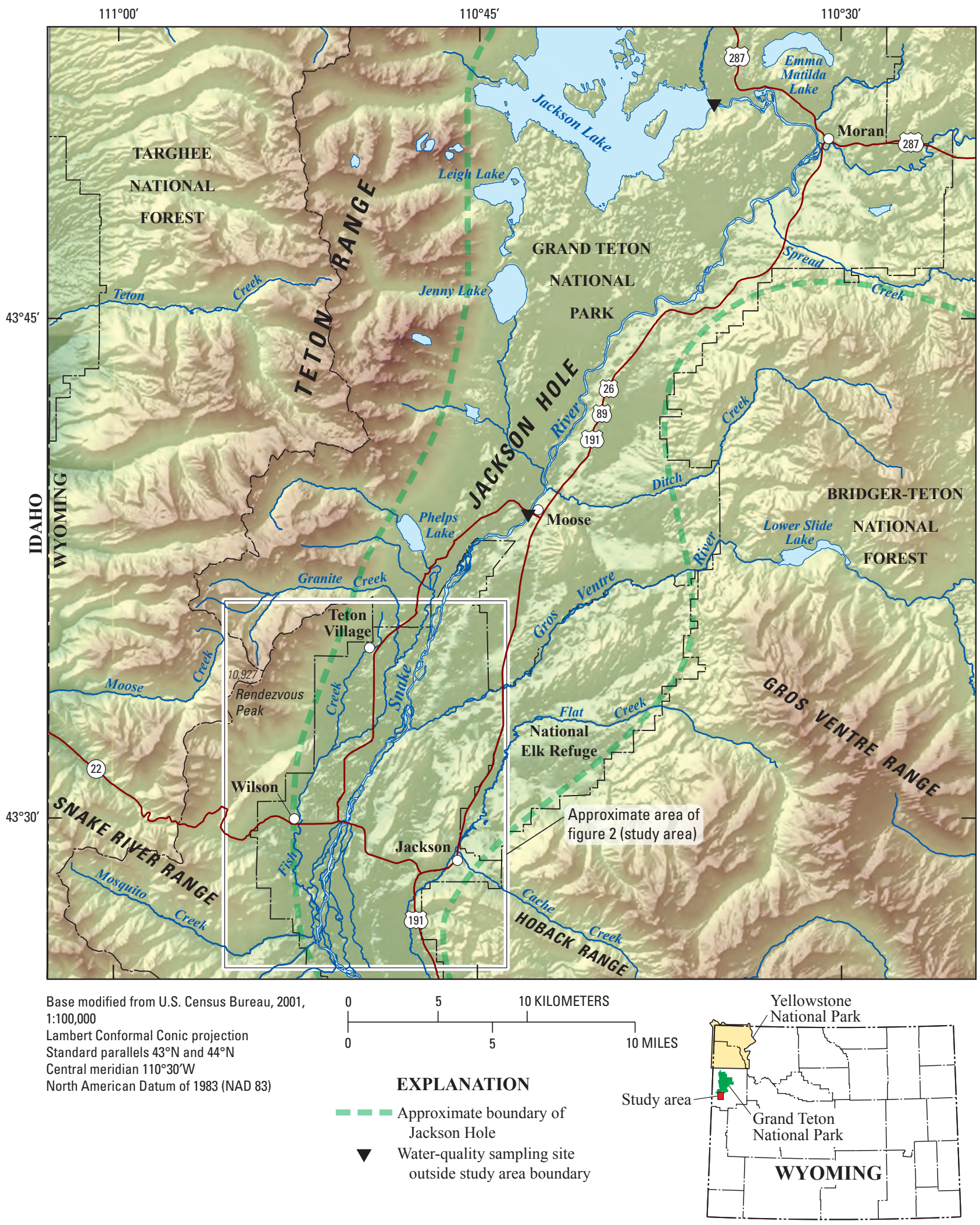

Figure 1. Location of Fish Creek as part of the Jackson Hole valley, Wyoming. 


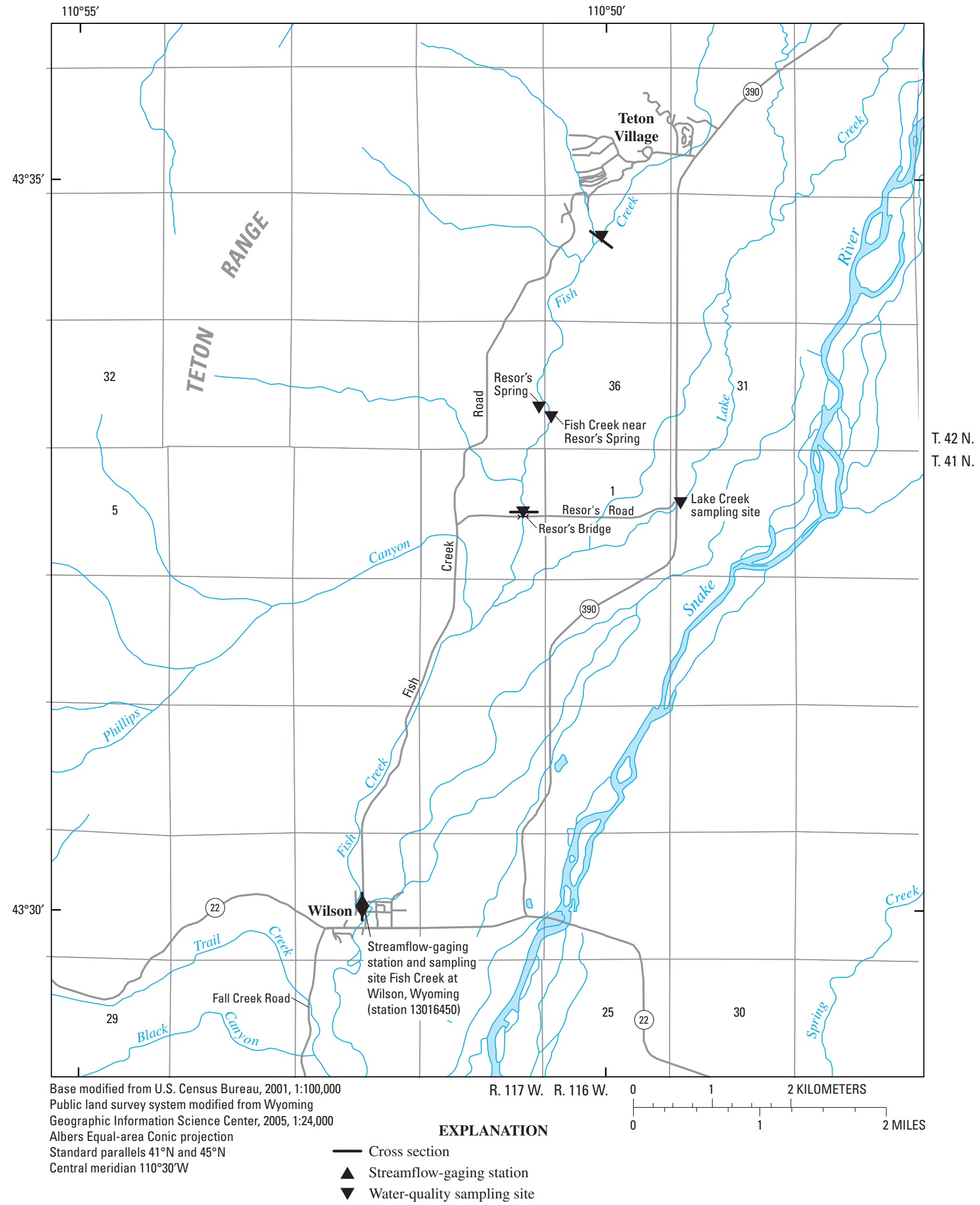

Figure 2. Locations of three well cross sections and selected miscellaneous water-quality sampling sites on and near Fish Creek, Wyoming. 
Chloride and Stable Isotopes of Hydrogen and Oxygen in and near Fish Creek, Teton County, Wyoming, 2005-06

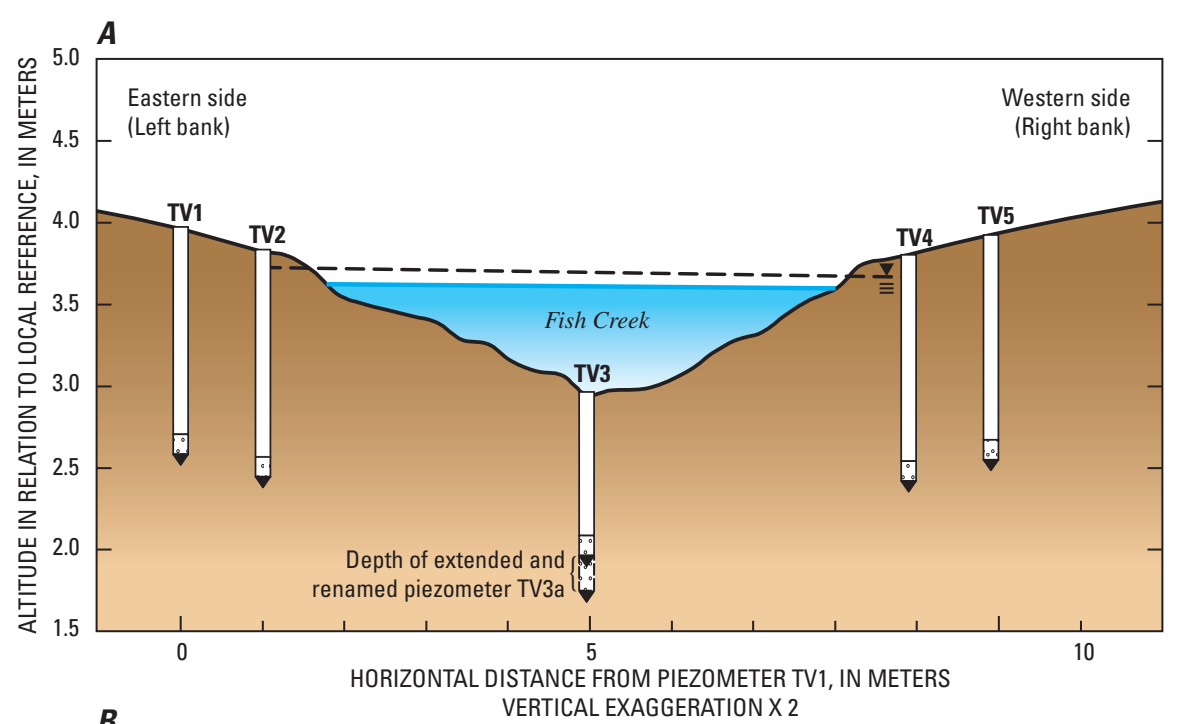

\section{EXPLANATION}

Land surface

- $\underset{\equiv}{\text { P }}$ - Groundwater altitude (August 24 or 25, 2005)

Stream stage (August 24 or 25, 2005)

TV5 Well number
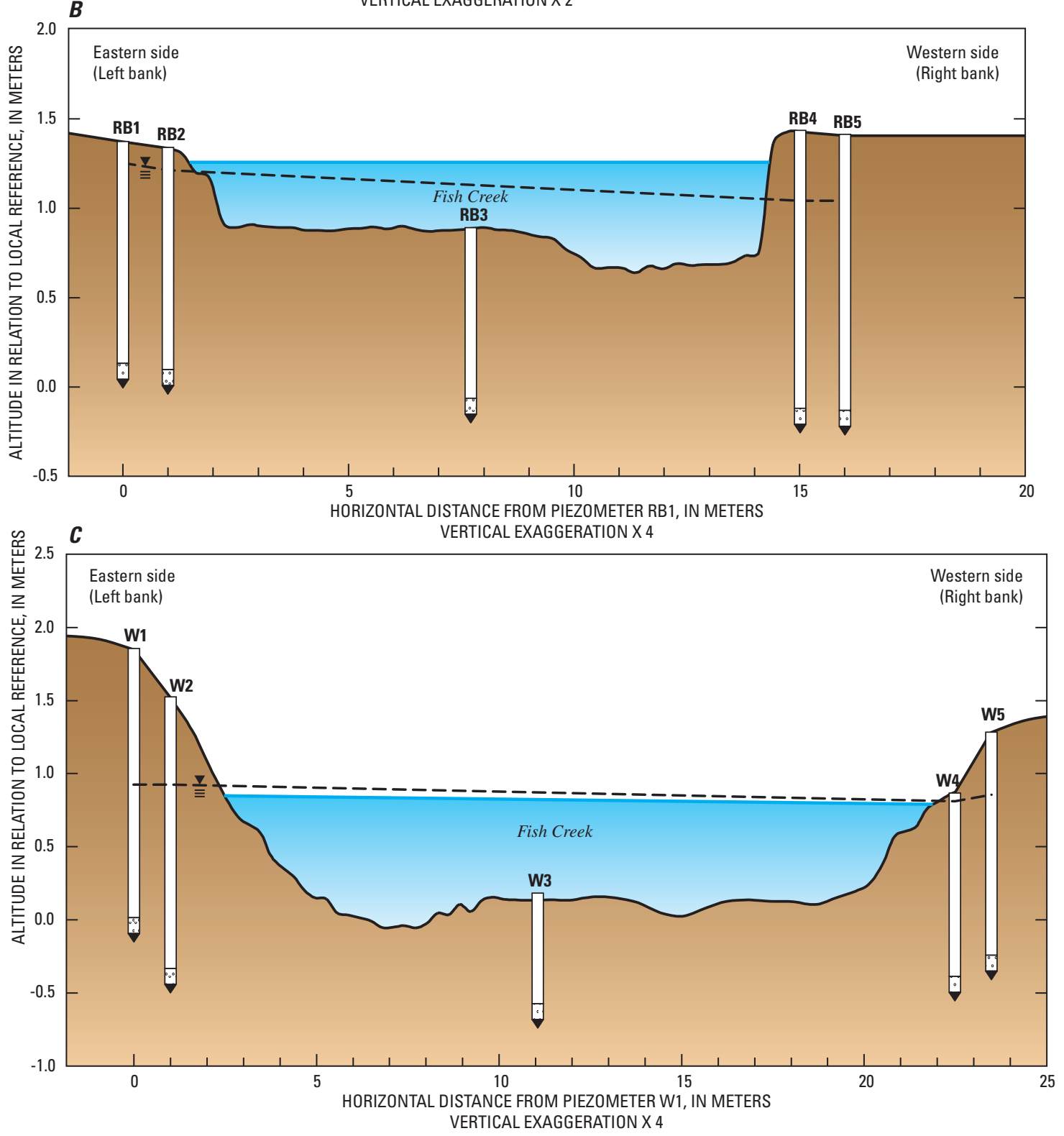

Figure 3. Channel geometry and well network at cross sections for $A$, Teton Village (TV); $B$, Resor's Bridge (RB); and $C$, Wilson (W). 
Table 1. Name and location of surface-water and groundwater water-quality sampling sites at the Teton Village, Resor's Bridge, and Wilson cross sections on Fish Creek, and miscellaneous sampling sites.

[USGS, U.S. Geological Survey; NAD 1983, North American Datum of 1983; --, not applicable]

\begin{tabular}{ccc}
\hline $\begin{array}{c}\text { Well or stream } \\
\text { mentation name and } \\
\text { USGS station number }\end{array}$ & $\begin{array}{c}\text { location' (latitude and } \\
\text { longitude in degrees, } \\
\text { minutes, seconds) } \\
\text { (NAD 83) }\end{array}$ & $\begin{array}{c}\text { Well depth } \\
\text { (meters below } \\
\text { land surface) }\end{array}$ \\
\hline
\end{tabular}

\begin{tabular}{|c|c|c|}
\hline \multicolumn{3}{|c|}{ Teton Village cross section } \\
\hline $\begin{array}{l}\text { TV1 } \\
433438110495801\end{array}$ & $\begin{array}{l}\text { N } 43^{\circ} 34^{\prime} 37.5^{\prime \prime} \\
\text { W } 110^{\circ} 50^{\prime} 02.7^{\prime \prime}\end{array}$ & 1.2 \\
\hline $\begin{array}{l}\text { TV2 } \\
433438110495802\end{array}$ & $\begin{array}{l}\text { N } 43^{\circ} 34^{\prime} 37.3^{\prime \prime} \\
\text { W } 110^{\circ} 50^{\prime} 02.6^{\prime \prime}\end{array}$ & 1.2 \\
\hline $\begin{array}{l}\text { TV3 }^{2} \\
433438110495803\end{array}$ & $\begin{array}{l}\mathrm{N} 43^{\circ} 34^{\prime} 37.2^{\prime \prime} \\
\mathrm{W} 110^{\circ} 50^{\prime} 02.8^{\prime \prime}\end{array}$ & .8 \\
\hline $\begin{array}{l}\text { TV3a }{ }^{3} \\
433438110495803\end{array}$ & $\begin{array}{l}\text { N } 43^{\circ} 34^{\prime} 37.2^{\prime \prime} \\
\text { W } 110^{\circ} 50^{\prime} 02.8^{\prime \prime}\end{array}$ & 1.4 \\
\hline $\begin{array}{l}\text { TV4 } \\
433438110495804\end{array}$ & $\begin{array}{l}\mathrm{N} 43^{\circ} 34^{\prime} 37.2^{\prime \prime} \\
\mathrm{W} 110^{\circ} 50^{\prime} 03.0^{\prime \prime}\end{array}$ & 1.2 \\
\hline $\begin{array}{l}\text { TV5 } \\
433438110495805\end{array}$ & $\begin{array}{l}\mathrm{N} 43^{\circ} 34^{\prime} 37.2^{\prime \prime} \\
\mathrm{W} 110^{\circ} 50^{\prime} 03.1^{\prime \prime}\end{array}$ & 1.2 \\
\hline $\begin{array}{l}\text { TVck (Fish Creek near } \\
\text { Teton Village) } \\
433438110495806\end{array}$ & $\begin{array}{l}\text { N } 43^{\circ} 34^{\prime} 38^{\prime \prime} \\
\text { W } 110^{\circ} 50^{\prime} 01^{\prime \prime}\end{array}$ & -- \\
\hline \multicolumn{3}{|c|}{ Resor's Bridge cross section } \\
\hline $\begin{array}{l}\text { RB1 } \\
433247110504501\end{array}$ & $\begin{array}{l}\text { N } 43^{\circ} 32^{\prime} 44.5^{\prime \prime} \\
\text { W } 110^{\circ} 50^{\prime} 46.6^{\prime \prime}\end{array}$ & 1.2 \\
\hline $\begin{array}{l}\text { RB2 } \\
433247110504502\end{array}$ & $\begin{array}{l}\mathrm{N} 43^{\circ} 32^{\prime} 44.5^{\prime \prime} \\
\mathrm{W} 110^{\circ} 50^{\prime} 46.6^{\prime \prime}\end{array}$ & 1.2 \\
\hline $\begin{array}{l}\text { RB3 } \\
433247110504503\end{array}$ & $\begin{array}{l}\text { N } 43^{\circ} 32^{\prime} 44.5^{\prime \prime} \\
\text { W } 110^{\circ} 50^{\prime} 46.9^{\prime \prime}\end{array}$ & 1.0 \\
\hline $\begin{array}{l}\text { RB4 } \\
433247110504504\end{array}$ & $\begin{array}{l}\text { N } 43^{\circ} 32^{\prime} 44.5^{\prime \prime} \\
\text { W } 110^{\circ} 50^{\prime} 47.3^{\prime \prime}\end{array}$ & 1.5 \\
\hline $\begin{array}{l}\text { RB5 } \\
433247110504505\end{array}$ & $\begin{array}{l}\text { N } 43^{\circ} 32^{\prime} 44.4^{\prime \prime} \\
\text { W } 110^{\circ} 50^{\prime} 47.3^{\prime \prime}\end{array}$ & 1.5 \\
\hline $\begin{array}{l}\text { RBck (Fish Creek near } \\
\text { Resor's Bridge) } \\
433247110504506\end{array}$ & $\begin{array}{l}\text { N } 43^{\circ} 32^{\prime} 47^{\prime \prime} \\
\text { W } 110^{\circ} 50^{\prime} 48^{\prime \prime}\end{array}$ & -- \\
\hline
\end{tabular}

\begin{tabular}{|c|c|c|}
\hline $\begin{array}{l}\text { Well or stream instru- } \\
\text { mentation name and } \\
\text { USGS station number }\end{array}$ & $\begin{array}{c}\text { Well or stream } \\
\text { location' }^{1} \text { (latitude and } \\
\text { longitude in degrees, } \\
\text { minutes, seconds) } \\
\text { (NAD 83) }\end{array}$ & $\begin{array}{l}\text { Well depth } \\
\text { (meters below } \\
\text { land surface) }\end{array}$ \\
\hline \multicolumn{3}{|c|}{ Wilson cross section } \\
\hline $\begin{array}{l}\text { W1 } \\
433003110521501\end{array}$ & $\begin{array}{l}\text { N } 43^{\circ} 30^{\prime} 03.2^{\prime \prime} \\
\text { W } 110^{\circ} 52^{\prime} 17.7^{\prime \prime}\end{array}$ & 2.1 \\
\hline $\begin{array}{l}\text { W2 } \\
433003110521502\end{array}$ & $\begin{array}{l}\text { N } 43^{\circ} 30^{\prime} 03.1^{\prime \prime} \\
\text { W } 110^{\circ} 52^{\prime} 17.6^{\prime \prime}\end{array}$ & 1.8 \\
\hline $\begin{array}{l}\text { W3 } \\
433003110521503\end{array}$ & $\begin{array}{l}\text { N } 43^{\circ} 30^{\prime} 02.9^{\prime \prime} \\
\text { W } 110^{\circ} 52^{\prime} 17.7^{\prime \prime}\end{array}$ & .8 \\
\hline $\begin{array}{l}\text { W4 } \\
433003110521504\end{array}$ & $\begin{array}{l}\text { N } 43^{\circ} 30^{\prime} 02.4^{\prime \prime} \\
\text { W } 110^{\circ} 52^{\prime} 17.8^{\prime \prime}\end{array}$ & 1.2 \\
\hline $\begin{array}{l}\text { W5 } \\
433003110521505\end{array}$ & $\begin{array}{l}\text { N 4330'02.4" } \\
\text { W } 110^{\circ} 52^{\prime} 17.8^{\prime \prime}\end{array}$ & 1.5 \\
\hline $\begin{array}{l}\text { Wck (Fish Creek at } \\
\text { Wilson) } \\
13016450\end{array}$ & $\begin{array}{l}\text { N } 43^{\circ} 30^{\prime} 03^{\prime \prime} \\
\text { W } 110^{\circ} 52^{\prime} 18^{\prime \prime}\end{array}$ & -- \\
\hline \multicolumn{3}{|c|}{ Miscellaneous site } \\
\hline $\begin{array}{l}\text { Jackson Lake outlet } \\
13010500\end{array}$ & 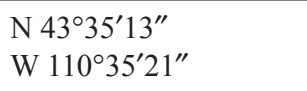 & -- \\
\hline $\begin{array}{l}\text { Snake River at Moose } \\
13013650\end{array}$ & $\begin{array}{l}\text { N 4339'15" } \\
\text { W } 110^{\circ} 42^{\prime} 56^{\prime \prime}\end{array}$ & -- \\
\hline $\begin{array}{l}\text { Resor’s Spring } \\
433225110504101\end{array}$ & $\begin{array}{l}\text { N } 43^{\circ} 33^{\prime} 25^{\prime \prime} \\
\text { W } 110^{\circ} 50^{\prime} 41^{\prime \prime}\end{array}$ & -- \\
\hline $\begin{array}{l}\text { Fish Creek near Resor's } \\
\text { Spring } \\
433323110503201\end{array}$ & 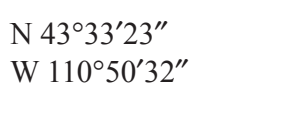 & -- \\
\hline $\begin{array}{l}\text { Lake Creek } \\
433247110491701\end{array}$ & $\begin{array}{l}\mathrm{N} 43^{\circ} 32^{\prime} 48^{\prime \prime} \\
\mathrm{W} 110^{\circ} 49^{\prime} 20^{\prime \prime}\end{array}$ & -- \\
\hline
\end{tabular}

${ }^{1}$ All latitude and longitude measurements were obtained with a handheld global positioning system (GPS).

${ }^{2}$ Setup in operation from October 2004 to October 2005.

${ }^{3}$ Setup in operation from October 2005 to October 2006. 


\section{Methods of Sampling and Analysis}

Surface-water samples were collected at eight locations: three at well cross section sites and five at miscellaneous sites. The creek width was divided into thirds and a dip sample collected at the midpoint of each third. The three samples were composited prior to processing (USGS, variously dated). Groundwater samples were collected from the wells methods described in Koterba (1998).

Water collected for chloride analysis was filtered through a 0.45 -micrometer capsule filter, and 20 milliliters $(\mathrm{mL})$ was contained in rinsed plastic bottles. Samples were then shipped to a USGS laboratory in Menlo Park, Calif., and analyzed on a Dionex ion chromatograph using the methods described in Fishman and Friedman (1989).

Water collected for the determination of stable isotopes of hydrogen and oxygen was collected by filling amber glass bottles to the top (no head space), capping, and then sealing with tape. All samples were shipped to a USGS laboratory in Menlo Park, Calif., for analysis using methods described in Lis and others (2008).

\section{Chloride Concentration and Stable Isotope Data}

Concentrations of chloride and the stable isotope data for hydrogen and oxygen in water are listed in tables 2 and 3 for 8 surface water and 15 groundwater sites. Samples were collected during May 11-13, 2005, August 23-26, 2005, December 20-22, 2005, and May 3-6, 2006. Groundwater sites for the Teton Village cross section (TV1-TV5) and surface water sites Fish Creek at Teton Village (TVck), Fish Creek near the spring known locally as Resor's Spring, and Lake Creek were dry during the December 2005 sampling, as noted in tables 2 and 3, respectively. Groundwater site TV5 also was dry during the May 2006 sampling.

Chloride concentrations in samples collected at the Teton Village cross section ranged from 2.9 to 26.4 milligrams per liter $(\mathrm{mg} / \mathrm{L}$; table 2$)$. This is the largest range in chloride concentrations among any set of data collected in the area, and all values are greater than most results from samples collected during this study. Chloride concentrations from samples collected at the Resor's Bridge cross section ranged from 1.2 to $4.9 \mathrm{mg} / \mathrm{L}$. Chloride concentrations in samples collected at the Wilson cross section ranged from 1.8 to $5.0 \mathrm{mg} / \mathrm{L}$, with the lowest concentrations during each sampling event for the sample from the stream.

The compositions of stable isotopes of water are reported using delta $(\delta)$ notation, which compares the ratio between heavy and light isotopes of a sample to that of a reference standard. Delta values are expressed as a difference, in parts per thousand or per mil, from values of a reference standard.
In this report, $\delta^{18} \mathrm{O}\left({ }^{18} \mathrm{O} /{ }^{16} \mathrm{O}\right)$ and $\delta^{2} \mathrm{H}\left({ }^{2} \mathrm{H} /{ }^{1} \mathrm{H}\right)$ values are reported in per mil relative to Vienna Standard Mean Ocean Water. The value for $\delta$ is calculated using the following equation (Clark and Fritz, 1997):

$$
\delta(\text { in per mil })=[(R x / R s)-1] \times 1,000
$$

where:

$$
\begin{aligned}
& R x \quad \text { is the ratio of the heavy-to-light isotope of the } \\
& \text { sample, and } \\
& \text { is the ratio of the heavy-to-light isotope of the } \\
& \text { applicable reference standard. }
\end{aligned}
$$

The isotopic composition of water changes in response to evaporation of the water and precipitation, as well as climatic differences. This change in the isotopic ratios can be used as a tool for characterizing the path water has taken through the hydrologic cycle (Clark and Fritz, 1997). The Global Meteoric Water Line (GMWL) is a global average of the isotopic relation between $\delta^{18} \mathrm{O}$ and $\delta^{2} \mathrm{H}$ in worldwide fresh surface water. Because of the changes that occur in the hydrologic cycle, a Local Meteoric Water Line (LMWL) is helpful for determining sources of groundwater recharge and for evaluating surface water and groundwater interaction (Benjamin and others, 2004). Stable isotope data for hydrogen and oxygen in water samples (table 3 ) collected in and near the three cross sections on Fish Creek are plotted on figures 4, 5, and 6, and are shown in relation to the GMWL (Clark and Fritz, 1997) and the LMWL (Benjamin and others, 2004).

\section{Summary}

Fish Creek, an approximately 25-kilometer long tributary to the Snake River, is located in Teton County in western Wyoming near the town of Wilson. Public concern about nuisance growths of aquatic plants in Fish Creek has been increasing in recent years. To more fully understand the hydrologic system and its possible relation to aquatic life in the stream, the U.S. Geological Survey in cooperation with the Teton Conservation District conducted a study to determine the interaction of local surface water and groundwater in and near Fish Creek. In conjunction with the surface water and groundwater interaction study, samples were collected for analysis of chloride and stable isotopes of hydrogen and oxygen in water.

Chloride concentrations ranged from 2.9 to 26.4 milligrams per liter near Teton Village, 1.2 to $4.9 \mathrm{mg} / \mathrm{L}$ near Resor's Bridge, and 1.8 to $5.0 \mathrm{mg} / \mathrm{L}$ near Wilson. The largest range in chloride concentrations was from samples collected near Teton Village, Wyo. Stable isotope data for hydrogen and oxygen in water samples collected in and near the three cross sections on Fish Creek are plotted in relation to the Global Meteoric Water Line and the Local Meteoric Water Line. 
Table 2. Concentration of chloride in water samples collected from surface water and groundwater at Teton Village (TV), Resor's Bridge (RB), and Wilson (W) cross sections on Fish Creek, and nearby surface-water bodies.

[Analyses of samples were performed by a U.S. Geological Survey laboratory in Menlo Park, Calif.; Dry, no sample collected because well or stream did not contain enough water to sample.]

\begin{tabular}{|c|c|c|c|c|}
\hline \multirow{2}{*}{ Well or stream name ${ }^{1}$} & \multicolumn{4}{|c|}{ Chloride concentration (milligrams per liter) } \\
\hline & May 11-13, 2005 & August 23-26, 2005 & December 20-22, 2005 & May 3-6, 2006 \\
\hline \multicolumn{5}{|c|}{ Teton Village cross section } \\
\hline TV1 & 4.4 & 3.1 & Dry & 7.2 \\
\hline TV2 & 3.5 & 2.9 & Dry & 6.2 \\
\hline TV3 & 6.5 & 3.4 & Dry & 26.4 \\
\hline TV4 & 13.3 & 7.7 & Dry & 14.4 \\
\hline TV5 & 14.0 & 3.2 & Dry & Dry \\
\hline TVck & 7.2 & 4.0 & Dry & 17.0 \\
\hline \multicolumn{5}{|c|}{ Resor's Bridge cross section } \\
\hline RB1 & 2.8 & 1.3 & 2.7 & 1.2 \\
\hline RB2 & 2.9 & 1.4 & 2.8 & 2.1 \\
\hline RB3 & 3.0 & 3.2 & 4.9 & 4.9 \\
\hline RB4 & 3.4 & 2.6 & 3.0 & 2.5 \\
\hline RB5 & 2.2 & 2.6 & 3.1 & 2.9 \\
\hline RBck & 2.2 & 2.9 & 2.9 & 3.2 \\
\hline \multicolumn{5}{|c|}{ Wilson cross section } \\
\hline W1 & 4.0 & 3.2 & 3.9 & 5.0 \\
\hline W2 & 4.5 & 3.1 & 3.8 & 4.7 \\
\hline W3 & 3.7 & 3.0 & 3.8 & 4.1 \\
\hline W4 & 3.4 & 3.0 & 3.6 & 3.8 \\
\hline W5 & 3.6 & 3.1 & 3.4 & 3.7 \\
\hline Wck & 1.8 & 2.9 & 2.1 & 1.9 \\
\hline \multicolumn{5}{|c|}{ Miscellaneous sites } \\
\hline Jackson Lake outlet & 6.3 & 5.9 & 7.0 & 6.1 \\
\hline Snake River at Moose & 2.2 & 4.5 & 4.4 & 1.8 \\
\hline Resor's Spring & 2.8 & 2.1 & 3.1 & 2.6 \\
\hline Fish Creek near Resor's Spring & 2.1 & 3.2 & Dry & 6.7 \\
\hline Lake Creek & 1.6 & 3.6 & Dry & .7 \\
\hline
\end{tabular}

${ }^{1}$ Locations of sites are defined in table 1. 
Table 3. Composition of isotopic fractions of hydrogen and oxygen (per mil) in water samples collected from surface water and groundwater at Teton Village (TV), Resor's Bridge (RB), and Wilson (W) cross sections on Fish Creek, and nearby surface-water bodies.

[The composition of stable isotopes is reported using delta $(\delta)$ notation, which indicates parts per thousand or per mil. Analyses of samples were performed at a U.S. Geological Survey laboratory in Menlo Park, Calif.; per mil, part per thousand; Dry, no sample collected because well or stream did not contain enough water to sample.]

\begin{tabular}{|c|c|c|c|c|}
\hline \multirow{2}{*}{ Well or stream name ${ }^{1}$} & \multicolumn{4}{|c|}{$\begin{array}{l}\delta^{18} 0, \delta^{2} H \\
\text { (per mil) }\end{array}$} \\
\hline & May 11-13, 2005 & August 23-25, 2005 & December 20-22, 2005 & May 3-6, 2006 \\
\hline \multicolumn{5}{|c|}{ Teton Village cross section } \\
\hline TV1 & $-17.58,-134.81$ & $-16.96,-132.75$ & Dry & $-18.37,-137.38$ \\
\hline TV3 & $-16.42,-127.48$ & $-17.49,-133.38$ & Dry & $-18.63,-136.34$ \\
\hline TV4 & $-17.58,-134.84$ & $-17.48,-133.81$ & Dry & $-18.08,-136.55$ \\
\hline TV5 & $-17.60,-132.91$ & $-17.54,-133.14$ & Dry & Dry \\
\hline TVck & $-18.77,-137.49$ & $-17.50,-132.51$ & Dry & $-17.88,-138.06$ \\
\hline $\mathrm{RB} 2$ & $-18.00,-137.59$ & $-17.26,-132.68$ & $-16.94,-132.62$ & $-18.85,-139.15$ \\
\hline RB3 & $-18.23,-138.36$ & $-16.96,-132.60$ & $-17.32,-134.39$ & $-18.17,-135.46$ \\
\hline RB4 & $-18.43,-137.99$ & $-17.47,-133.91$ & $-17.06,-133.09$ & $-18.05,-134.74$ \\
\hline RB5 & $-18.48,-136.74$ & $-17.54,-134.94$ & $-16.87,-132.53$ & $-17.68,-134.68$ \\
\hline RBck & $-16.93,-134.70$ & $-16.47,-132.35$ & $-17.00,-132.62$ & $-17.67,-136.26$ \\
\hline \multicolumn{5}{|c|}{ Wilson cross section } \\
\hline W1 & $-17.67,-136.29$ & $-17.58,-133.10$ & $-16.68,-133.11$ & $-17.42,-136.38$ \\
\hline \multicolumn{5}{|c|}{ Miscellaneous sites } \\
\hline Jackson Lake outlet & $-17.75,-136.29$ & $-16.61,-128.41$ & $-17.52,-132.85$ & $-17.22,-133.24$ \\
\hline Snake River at Moose & $-17.55,-136.71$ & $-17.45,-131.74$ & $-17.41,-134.00$ & $-18.39,-139.24$ \\
\hline Resor's Spring & $-17.31,-134.06$ & $-18.18,-133.93$ & $-17.19,-133.77$ & $-18.18,-134.62$ \\
\hline Fish Creek near Resor's Spring & $-17.48,-134.75$ & $-17.43,-133.37$ & Dry & $-18.00,-135.70$ \\
\hline Lake Creek & $-17.71,-138.48$ & $-17.31,-133.06$ & Dry & $-17.60,-136.28$ \\
\hline
\end{tabular}

${ }^{1}$ Locations of sites are defined in table 1. 


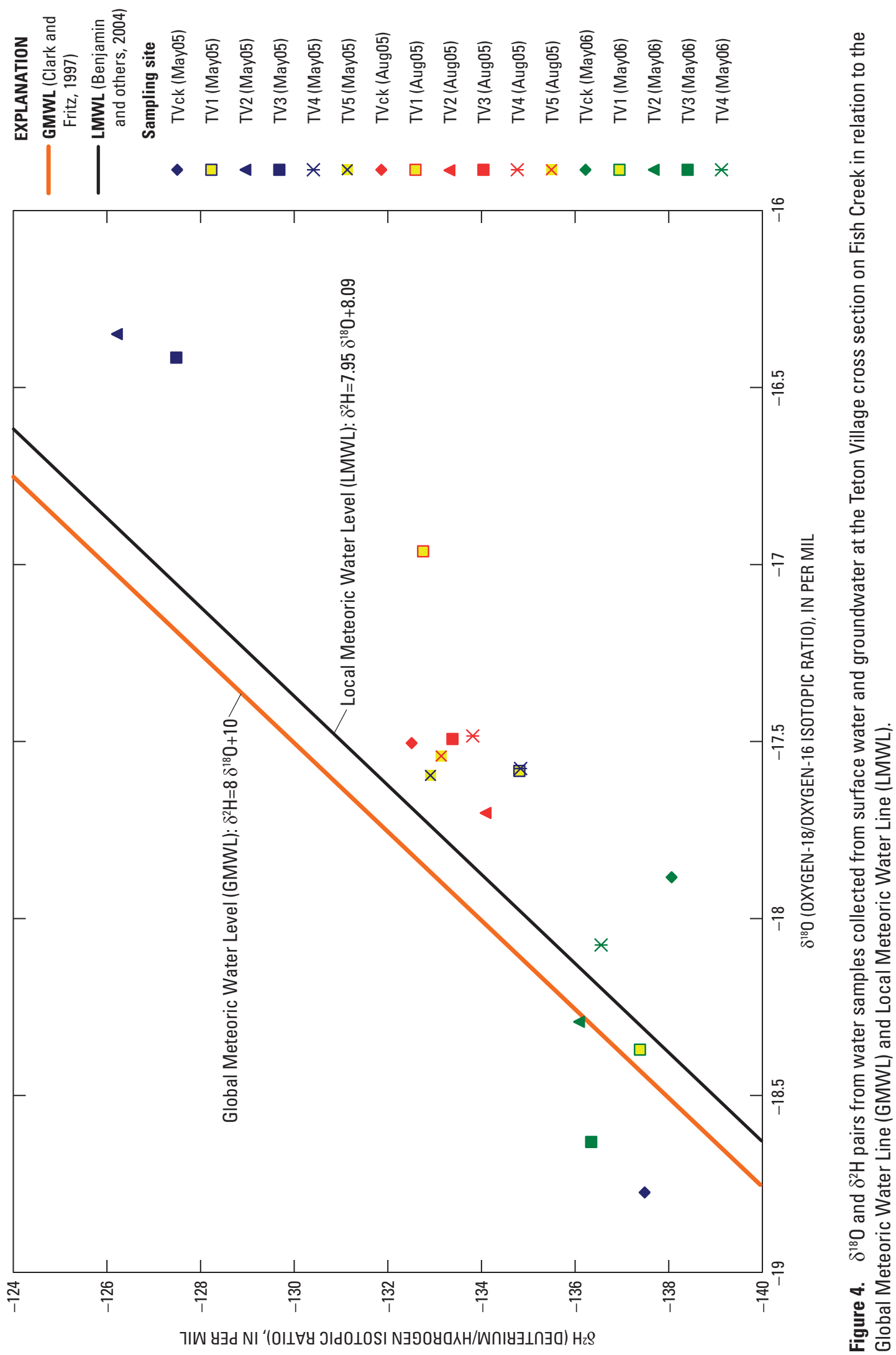




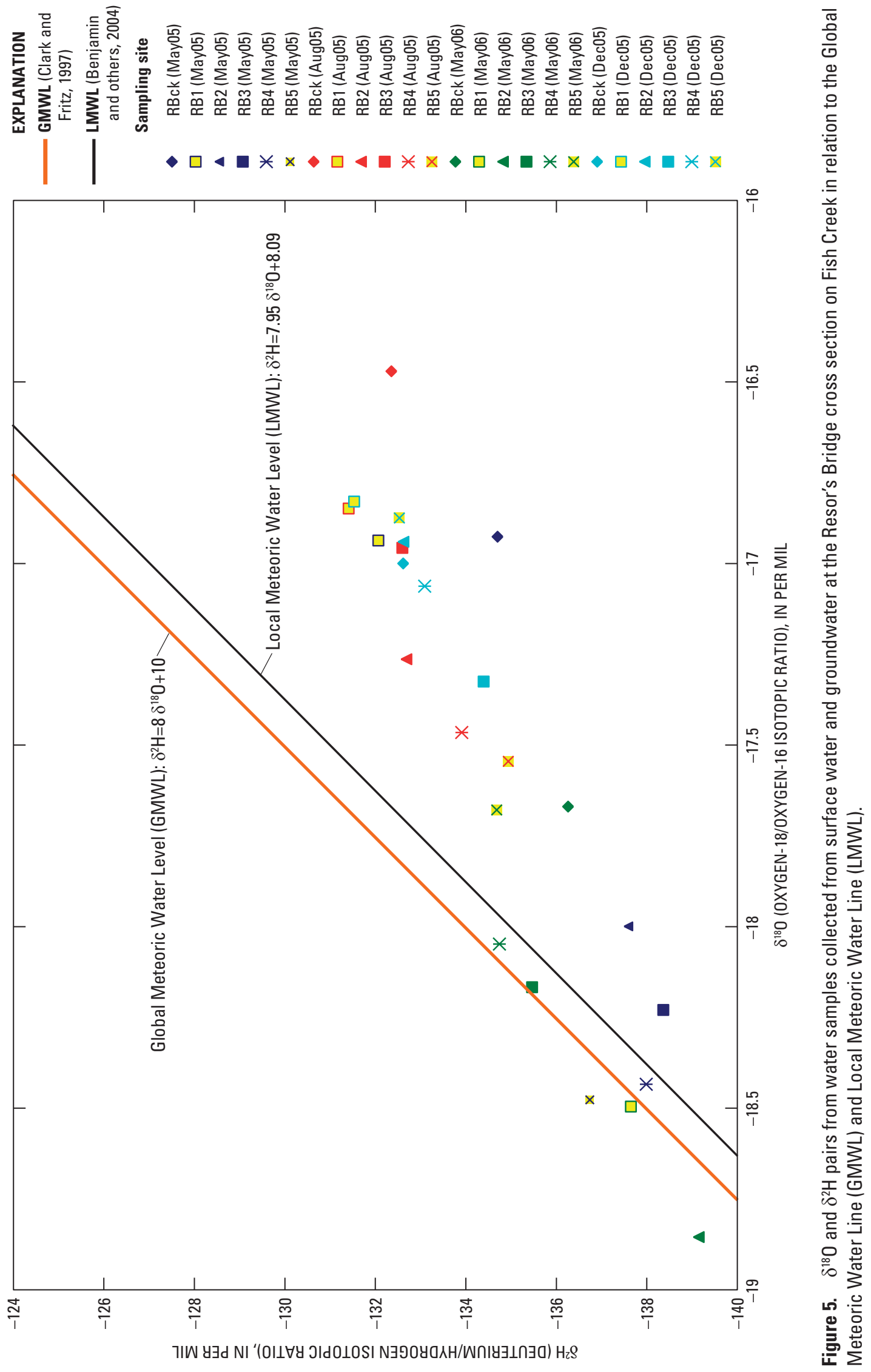




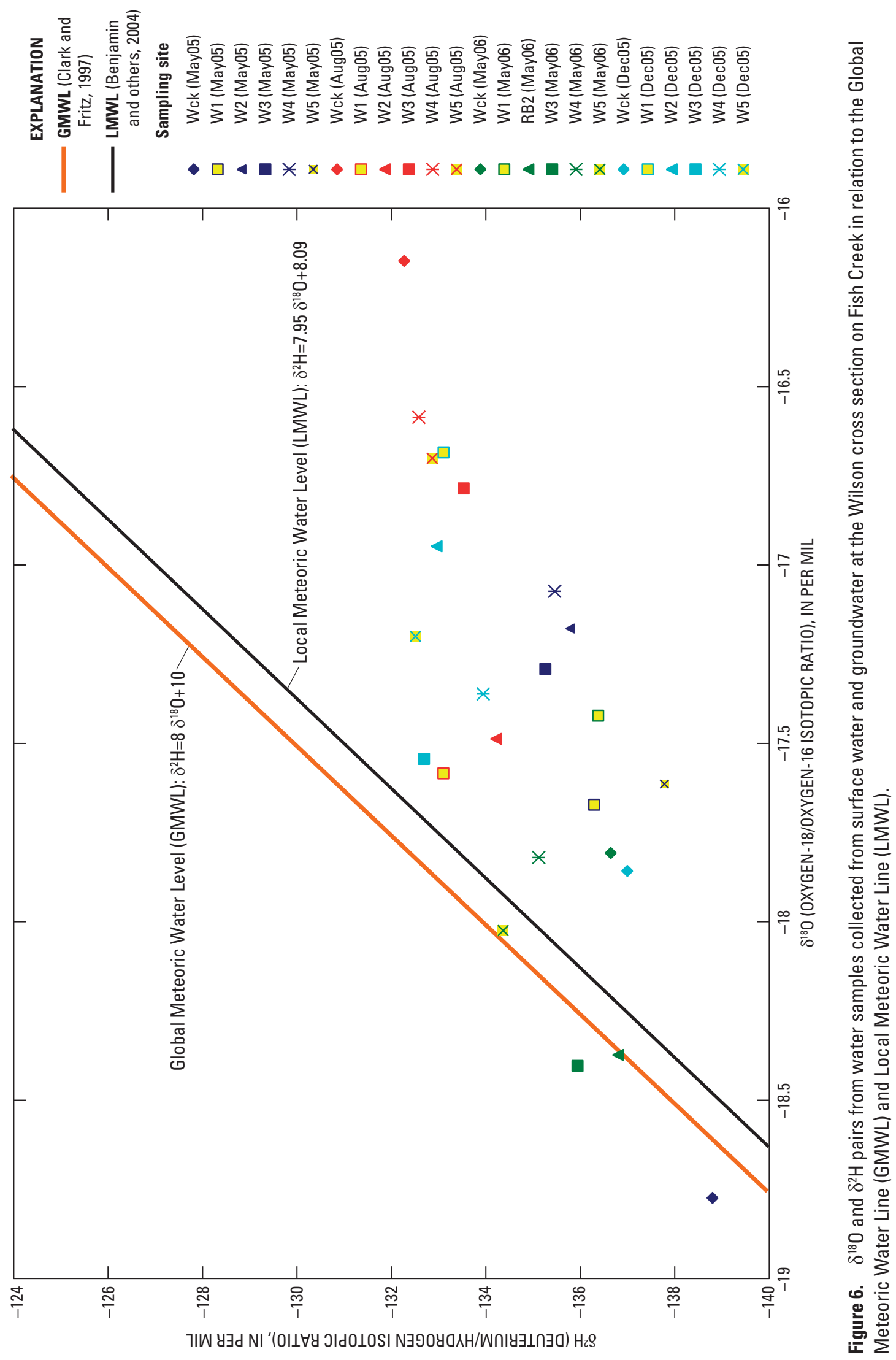




\section{References Cited}

Benjamin, Lyn, Knobel, L.L., Hall, L.F., Cecil, L.D, and Green, J.R., 2004, Development of a local meteoric water line for southeastern Idaho, western Wyoming, and southcentral Montana: U.S. Geological Survey Scientific Investigations Report 2004-5126, 17 p. Available at http://pubs. usgs.gov/sir/2004/5126/.

Clark, I.D., and Fritz, Peter, 1997, Environmental isotopes in hydrogeology: New York, Lewis Publishers, 328 p.

Eddy-Miller, C.A., Wheeler, J.D., and Essaid, H.I., 2009, Characterization of interactions between surface water and near-stream groundwater along Fish Creek, Teton County, Wyoming, by using heat as a tracer: U.S. Geological Survey Scientific Investigations Report 2009-5160, 53 p. Available at $h t t p: / / p u b s . u s g s . g o v / s i r / 2009 / 5160 /$.

Fishman, M.J., and Friedman, L.C., eds., 1989, Methods for determination of inorganic substances in water and fluvial sediments: U.S. Geological Survey Techniques of WaterResources Investigations, book 5, chap. A1, 545 p. Available at http://pubs.usgs.gov/twri/twri5-al/.

Koterba, M.T., 1998, Ground-water data-collection protocols and procedures for the National Water-Quality Assessment Program-Collection, documentation, and compilation of required site, well, subsurface, and landscape data for wells: U.S. Geological Survey Water-Resources Investigations Report 98-4107, 91p.
Lis, G., Wassenaar, L.I., and Hendry, M.J., 2008, Highprecision laser spectroscopy $\mathrm{D} / \mathrm{H}$ and ${ }^{18} \mathrm{O} /{ }^{16} \mathrm{O}$ measurements of microliter natural water samples: Analytical Chemistry, v. 80, p. $287-293$.

Swanson, R.B., Woodruff, R.E., Laidlaw, G.A., Watson, K.R., and Clark, M.L., 2002, Water-resources data, Wyoming, water year 2001, Volume 1. Surface Water: U.S. Geological Survey Water-Data Report WY-01-1, 518 p. Available at http://pubs.usgs.gov/wdr/WDR_WY_01/.

U.S. Geological Survey, variously dated, National field manual for the collection of water-quality data: U.S. Geological Survey Techniques of Water-Resources Investigations, book 9, Chaps. A1-A9, accessed December 14, 2009, at http://water.usgs.gov/owq/FieldManual/.

Wheeler, J.D., and Eddy-Miller, C.A., 2005, Seepage investigation on selected reaches of Fish Creek, Teton County, Wyoming, 2004: U.S. Geological Survey Scientific Investigations Report 2005-5133, 15 p. Available at http://pubs. usgs.gov/sir/2005/5133/.

Publishing support provided by:

Denver Publishing Service Center

For more information concerning this publication, contact:

Director, Wyoming Water Science Center

U.S. Geological Survey

2617 East Lincolnway, Suite B

Cheyenne, Wyoming 82001

(307) 778-2931

Or visit the Wyoming Water Science Center Web site at:

http://wy.water.usgs.gov/ 



\section{$\frac{1}{3}$}

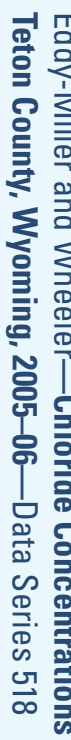

6 Printed on recycled paper 